\title{
Dimethylsulfoniopropionate (DMSP) in marine copepods and its relation with diets and salinity
}

\author{
Kam W. Tang*, Hans G. Dam, Pieter T. Visscher, Timothy D. Fenn \\ Department of Marine Sciences, University of Connecticut, Groton, Connecticut 06340, USA
}

\begin{abstract}
The main goal of this study was to assess the effects of algal diets and water salinity on the bodily content of dimethylsulfoniopropionate (DMSP) in estuarine copepods. In laboratory experiments, Temora longicornis contained more DMSP when fed DMSP-rich Tetraselmis impellucida (prasinophyte) than when fed DMSP-poor Dunaliella tertiolecta (chlorophyte). The DMSP content of $T$. longicornis after gut clearance was curvilinearly related to the ingestion rate. These observations suggest that the copepods incorporated the dietary source of DMSP into their body tissue. On the same diet, $T$. longicornis contained more DMSP at higher salinity, indicating an osmoregulatory function of DMSP. However, DMSP appears to be a minor osmolyte compared with free amino acids. The DMSP content of $T$. longicornis decreased faster in response to a decrease in salinity than it increased with an increase in salinity, implicating separate mechanisms for accumulation and removal of DMSP in the copepod. We also measured the bodily content of DMSP from field-collected animals. Five species of calanoid copepods from Long Island Sound contained DMSP, not associated with gut content, which varied interspecifically from 0.02 to $1.03 \mathrm{nmol}$ ind. ${ }^{-1}$ Carbon-specific DMSP content of the copepods was comparable to that reported for some diatoms, chlorophytes and cryptophytes. We argue that copepod biomass may, at times, represents a substantial source of particulate DMSP in the water column.
\end{abstract}

KEY WORDS: DMSP · Copepod biomass $\cdot$ Diets $\cdot$ Salinity shift · Osmoregulation

\section{INTRODUCTION}

Dimethylsulfoniopropionate (DMSP) is a globally important sulfur compound because it can be broken down chemically and biologically into dimethyl sulfide (DMS) (Dacey \& Blough 1987, Stefels \& van Boekel 1993, Ledyard \& Dacey 1994), the dominant sulfur species for sea-air exchange (Lovelock et al. 1972, Nguyen et al. 1978, 1983, Andreae \& Raemdonck 1983) and an agent for formation of cloud condensation nuclei (Andreae 1990). DMSP is synthesized by many phytoplankton species as an osmolyte (Kirst 1996) and is also found in a variety of marine organisms (Dacey et al. 1994, Hill et al. 1995, references in Nakajima 1996). There has also been work on the effects of heterotrophic protozoans on the dynamics of DMS and DMSP (e.g. Belviso et al. 1990, Wolfe et al. 1994, Wolfe \& Steinke 1996). Despite the large biomass of zooplankton in the ocean and the possible uptake of

\footnotetext{
·E-mail: kwt94001@uconnvm.uconn.edu
}

DMSP by zooplankton through ingestion of phytoplankton (Dacey \& Wakeham 1986, Kwint \& Kramer 1996, Kwint et al. 1996), surprisingly little information is available on how zooplankton affect the dynamics of DMSP in the ocean. Current models of DMSP dynamics often exclude planktonic grazers (Charlson et al. 1987, Andreae 1990, Malin 1996, Visscher 1996). Although the model by Gabric et al. (1993) includes planktonic grazers, the model considers zooplankton merely as mediators of DMSP fluxes through sloppy feeding, enzymatic digestion or fecal pellet formation (e.g. Dacey \& Wakeham 1986, Kiene \& Bates 1990, Daly \& DiTullio 1996). The possibility that zooplankton biomass is a significant fraction of the total DMSP pool has received little attention. To our knowledge, the only consideration of such a possibility has been the suggestion by Wolfe (1992) that on the order of $10 \%$ of the total DMSP pool in the north Pacific was due to copepod biomass. Another neglected area of study is the role of DMSP as an osmolyte in zooplankton. Although there is evidence that coastal and estuarine 
zooplankton can osmoregulate by adjusting bodily free amino acids (Farmer \& Reeve 1978, Farmer 1980, Burton \& Feldman 1982); the hypothesis that DMSP is used as an osmolyte in zooplankton has not been studied.

In the present study, we test the hypotheses that (1) marine copepods contain DMSP independently of gut contents, (2) the DMSP content of copepods is determined by their diet, and (3) copepods use DMSP for osmoregulation. We show that the amount of DMSP in copepods depends on food type and food concentration as well as external salinity. Furthermore, we report the presence of DMSP in copepod biomass and assess the copepod contribution to the total DMSP pool in Long Island Sound.

\section{MATERIALS AND METHODS}

DMSP in field-collected copepods. Copepods and surface seawaters were collected from eastern Long Island Sound $\left(41^{\circ} 18^{\prime} 26^{\prime \prime} \mathrm{N}, 70^{\circ} 03^{\prime} 27^{\prime \prime} \mathrm{W}\right)$ between May and October of 1997 with a standard ring net (0.5 m mouth diameter, $202 \mu \mathrm{m}$ mesh with a solid cod end). Upon return to the laboratory, the copepods were sorted by species. DMSP contents of field-collected copepods were measured before or after gut clearance ( 3 to $24 \mathrm{~h}$ in GF/F filtered surface seawater). Ten to 100 individuals were put in each $5 \mathrm{ml}$ serum bottle. All serum bottles were sealed with butyl caps and aluminum seals and stored at $-70^{\circ} \mathrm{C}$ until DMSP measurements were conducted. Samples of copepods were also collected for bodily carbon content measurements using a Carlo-Erba EA1108 CHNS elemental analyzer. For laboratory experiments between April and July of 1998, copepods were collected in the same manner and were maintained in a walk-in environmental chamber $\left(9.5^{\circ} \mathrm{C}\right.$ and a $12: 12 \mathrm{~h}$ light: dark cycle) upon return to the laboratory.

Phytoplankton cultures. Tetraselmis impellucida PLY 429 (Prasinophyceae) and Dunaliella tertiolecta WHO 1 (Chlorophyceae) were used for laboratory experiments. T. impellucida is a DMSP-rich food (Keller \& Korjeff-Bellows 1996), D. tertiolecta represents a DMSPpoor food (Matrai \& Keller 1994) and both have similar cell size ( 7.5 to $8 \mu \mathrm{m}$ equivalent spherical diameter). Both phytoplankton species were grown in $\mathrm{f} / 2$ medium (Guillard 1975) at 2 different salinities: 30 and $20 \%$. Growth media were prepared with $0.2 \mu \mathrm{m}$ (Vacucap) filtered and autoclaved Instant Ocean artificial seawater. All phytoplankton cultures were grown in a walk-in environmental chamber set at $9.5^{\circ} \mathrm{C}$ with a $12: 12 \mathrm{~h}$ light: dark cycle. Only $D$. tertiolecta cultures were bubbled gently with filtered air. T. impellucida cultures were not bubbled because bubbling made the cells adhere to the wall of the vessels (pers. obs.).
Diet and salinity effect experiments. Diet and salinity effect experiments were conducted 3 times between April and May 1998. Before the start of the experiments, field-collected Temora longicornis were acclimated in $2 \times 10^{4}$ cells $\mathrm{ml}^{-1}$ of each of the 4 food media: 30 and $20 \%$ Tetraselmis impellucida; 30 and $20 \%$ Dunaliella tertiolecta. Cell densities of the phytoplankton cultures were determined with an Elzone 280PC particle counter and aliquots of phytoplankton cultures were added to $0.2 \mu \mathrm{m}$ filtered artificial seawater of the appropriate salinity to make up the desired food concentrations in 11 polycarbonate bottles. Since the food media were prepared by adding the phytoplankton cultures to filtered seawater of the same salinity, the phytoplankton cells did not experience any change in external salinity throughout the experiments. Fifteen to $20 \mathrm{~T}$. longicornis (CV-adult female) were acclimated in each food medium in the environmental chamber $\left(9.5^{\circ} \mathrm{C}\right.$ and $12: 12 \mathrm{~h}$ light : dark cycle) for 2 to $3 \mathrm{~d}$. During acclimation, food particles were maintained in suspension by gentle bubbling with filtered air. Aliquots of phytoplankton cultures were added daily to restore the food concentrations as necessary.

Food media for experiments were prepared by adding aliquots of phytoplankton cultures to $0.2 \mu \mathrm{m}$ filtered artificial seawater of the appropriate salinity in polycarbonate bottles. Final food concentrations were measured with the Elzone particle counter. Duplicates of $5 \mathrm{ml}$ aliquots of each food medium were filtered onto GF/F filters under gravity and briefly rinsed with artificial seawater. The filters were then put in $5 \mathrm{ml}$ serum bottles, sealed and stored at $-70^{\circ} \mathrm{C}$ until DMSP measurements were conducted. At the end of acclimation, live copepods with intact appendages were transferred to the experimental food media (1 1 of the same diet and salinity). Control bottles without copepods were also set up. All bottles were topped off with food media, sealed with parafilm and fastened onto a spinning plankton wheel (2 rpm).

After 24 h of incubation in the environmental chamber $\left(9.5^{\circ} \mathrm{C}, 12: 12 \mathrm{~h}\right.$ light: dark cycle), the final food concentrations were measured with the Elzone particle counter. Three to 5 copepods from each bottle were gently collected on a $200 \mu \mathrm{m}$ nylon sieve, briefly rinsed in artificial seawater of the appropriate salinity, and then transferred to $120 \mathrm{ml}$ of $0.2 \mu \mathrm{m}$ filtered artificial seawater of the appropriate salinity for gut clearance for $12 \mathrm{~h}$. Given an average gut passage time of $30 \mathrm{~min}$ for Temora longicornis at $9^{\circ} \mathrm{C}$ (Dam \& Peterson 1988), $12 \mathrm{~h}$ was more than sufficient to empty the guts of the copepods. Visual examination with a dissecting microscope also confirmed the absence of gut content after gut clearance. Individual copepods were then transferred into $5 \mathrm{ml}$ serum bottles (1 copepod per bottle), sealed and stored at $-70^{\circ} \mathrm{C}$ until DMSP measurements 
were conducted. Remaining copepods from each bottle were used for the salinity shift experiments (see below).

Salinity shift experiments. At the end of the first $24 \mathrm{~h}$ incubation (see 'Diet and salinity effect experiments'), the remaining Temora longicornis from each bottle were divided into 2 groups. One group was transferred to a fresh food medium of the same food species $(2 \times$ $10^{4}$ cells $\mathrm{ml}^{-1}$ of Tetraselmis impellucida or Dunaliella tertiolecta) and salinity (30 or $20 \%$ ). The other group was transferred to the same food species of the opposite salinity (i.e. 30 to $20 \%$ and vice versa). After another $24 \mathrm{~h}$ of incubation, the copepods were transferred to filtered artificial seawater of the corresponding final salinity for gut clearance. After $12 \mathrm{~h}$ of gut clearance, individual copepods were collected for DMSP measurement.

Food concentration experiment. A separate set of experiments was conducted in July 1998 to determine the effects of food concentrations on the DMSP content of Temora longicornis. Thirty $T$. longicornis females (CV-adult) were acclimated in either high $\left(2 \times 10^{4}\right.$ cells $\mathrm{ml}^{-1}$ at 30 and $20 \%$ ) or low concentration $\left(10^{3}\right.$ cells $\mathrm{ml}^{-1}$ at 30 and $20 \%$ ) of Tetraselmis impellucida for $3 \mathrm{~d}$. At the end of acclimation, 24 to $26 \mathrm{~T}$. longicornis were transferred to 11 polycarbonate bottles filled with fresh food media of the same salinity. After $24 \mathrm{~h}$ of incubation, 7 to 10 copepods were removed from each bottle and put individually in serum bottles for DMSP measurement before gut clearance. Remaining copepods were transferred to filtered artificial seawater of the corresponding salinity for gut clearance. After $12 \mathrm{~h}$ of gut clearance, copepods were put individually in serum bottles for DMSP measurement.

DMSP measurements. DMSP in the samples was converted stoichiometrically to DMS by cold-alkaline hydrolysis (Dacey \& Blough 1987). Samples were digested overnight with $5 \mathrm{ml}$ of $1 \mathrm{~N} \mathrm{NaOH}$. Between
May and October of 1997, our purge-and-trap system and flame photometric detector (FPD) were not available; therefore, DMSP content of field-collected copepods was measured by injecting the resultant DMS in the headspace into a Shimadzu (GC-14A) gas chromatograph equipped with a Carbopak BHT column (Supelco) and a flame ionization detector (FID). The FID was calibrated with standard DMS (Sigma Co.). For the laboratory experiments between April and July 1998, we digested the samples with $5 \mathrm{ml}$ of $1 \mathrm{~N}$ $\mathrm{NaOH}$ and measured the resultant DMS in the aqueous phase with the purge-and-trap technique (Kiene \& Service 1991) and a FPD. The FPD was calibrated with standard DMSP solutions made by dissolving standard DMSP salt (University of Groningen, The Netherlands; $>98 \%$ purity) in sterilized distilled water to various concentrations. The standard DMSP solutions were hydrolyzed to DMS with $\mathrm{NaOH}$, and the resultant DMS was purged, trapped and measured on the gas chromatograph in the same manner as the samples.

\section{RESULTS}

\section{DMSP in field-collected copepods}

Five species of calanoid copepods were collected during the study period. Temora Iongicornis and Centropages hamatus were most common in the winter and Acartia tonsa in the summer. Labidocera sp. and Paracalanus crassirostris were found occasionally in the summer. All species contained DMSP (Table 1). Large inter-specific variation (1 to 2 orders of magnitude) was observed but did not appear to be related to body size. Among the species studied, T. longicornis contained the most DMSP per individual, followed by

Table 1. DMSP content of copepods from Long Island Sound, USA. Copepod gut was cleared in GF/F filtered surface seawater Copepods without gut clearance (0 h of gut clearance duration) are presented separately. DMSP was converted to DMS by coldalkaline hydrolysis and the head-space DMS was then quantified with GC/FID. Carbon content was measured with a Carlo-Erba EA 1108 CHNS elemental analyzer. n: no. of measurements; each measurement consisted of 10 to 100 copepods, nd: no data

\begin{tabular}{|c|c|c|c|c|c|c|c|c|c|}
\hline Species & Period & Sex & $\begin{array}{l}\text { Approx. } \\
\text { body length } \\
\text { (mm) }\end{array}$ & $\begin{array}{l}\text { Gut clearance } \\
\text { duration } \\
\text { (h) }\end{array}$ & & $\begin{array}{l}\text { MSP cor } \\
\text { mol ind } \\
\text { Mean }\end{array}$ & $\begin{array}{l}\text { ntent } \\
\left.{ }^{-1}\right) \\
S D\end{array}$ & $\begin{array}{c}\text { Carbon } \\
\left(\mu \mathrm{g} C \text { ind }^{-1}\right)\end{array}$ & $\begin{array}{c}\text { C-specific } \\
\text { DMSP content } \\
\left(m g \text { DMSP } g^{-1} \mathrm{C}\right)\end{array}$ \\
\hline Temora longicornis & May-Jun & F & 1 & $3-18$ & 29 & 1.03 & 0.59 & 13.58 & 10.28 \\
\hline Temora longicornis & May & M & 1 & 3 & 8 & 1.03 & 0.22 & nd & nd \\
\hline Centropages hamatus & Jun & F & $1-1.2$ & $3-18$ & 2 & 0.81 & 0.12 & 10.32 & 10.54 \\
\hline Acartia tonsa & Jul-Oct & F & 0.5 & $21-24$ & 22 & 0.02 & 0.03 & 4.60 & 0.63 \\
\hline Acartia tonsa & Aug-Oct & F & 0.5 & 0 & 7 & 0.02 & 0.01 & 4.60 & 0.63 \\
\hline Labidocera sp. & Oct & $F$ & $2-2.5$ & 24 & 4 & 0.09 & 0.02 & 38.93 & 0.32 \\
\hline Labidocera sp. & Sep-Oct & $\mathrm{F}$ & $2-2.5$ & 0 & 3 & 0.06 & 0.01 & 38.93 & 0.22 \\
\hline Labidocera sp. & Sep-Oct & $M$ & 2 & 0 & 4 & 0.04 & 0.01 & nd & nd \\
\hline Paracalanus crassirostris & Oct & nd & 0.2 & 24 & 1 & 0.01 & nd & nd & nd \\
\hline Paracalanus crassirostris & Sep & nd & 0.2 & 0 & 2 & 0.01 & 0.00 & nd & nd \\
\hline
\end{tabular}


Table 2. Results for diet and salinity effect experiments. DMSP contents of Temora longicornis after 12 h gut clearance are presented. Ingestion rates were calculated assuming zero phytoplankton growth and constant phytoplankton DMSP content during the experments (see text). $n=$ sample size. DMSP was converted to DMS by cold-alkaline hydrolysis and the aqueous phase DMS was then quantified with purge-and-trap technique. Turnover time was calculated as DMSP content of $T$ longicornis divided by ingestion rate in terms of DMSP

\begin{tabular}{|c|c|c|c|c|c|c|c|c|}
\hline Expt & Food type & $\mathrm{n}$ & $\begin{array}{c}\text { Salinity } \\
(\% \circ)\end{array}$ & $\begin{array}{c}\text { Food } \\
\text { concentration } \\
\text { (nmol DMSP } \\
\left.\mathrm{ml}^{-1}\right)\end{array}$ & $\begin{array}{l}\text { Ingestion } \\
\text { rate } \\
\left(10^{4} \text { cells }\right. \\
\left.\text { ind } .^{-1} \mathrm{~d}^{-1}\right)\end{array}$ & $\begin{array}{l}\text { Ingestion } \\
\text { rate } \\
\text { (nmol DMSP } \\
\text { ind. }{ }^{-1} \mathrm{~d}^{-1} \text { ) }\end{array}$ & $\begin{array}{l}\text { DMSP content of } \\
\text { Temora longicornis } \\
\text { (mean } \pm \mathrm{SE}_{i} \\
\text { nmol ind. } .^{-1} \text { ) }\end{array}$ & $\begin{array}{c}\text { Turnover } \\
\text { time } \\
\text { (d) }\end{array}$ \\
\hline \multirow[t]{4}{*}{3 Apr } & Tetraselmis impellucida & 4 & 30 & 0.56 & 22 & 5.64 & $5.55 \pm 0.82$ & 1.0 \\
\hline & & 4 & 20 & 0.34 & 9 & 1.49 & $0.89 \pm 0.19$ & 0.6 \\
\hline & Dunaliella tertiolecta & 4 & 30 & 0.01 & 9 & 0.05 & $0.42 \pm 0.08$ & 8.4 \\
\hline & & 3 & 20 & 0.01 & 13 & 0.08 & $0.14 \pm 0.02$ & 1.7 \\
\hline \multirow[t]{4}{*}{$21 \mathrm{Apr}$} & Tetraselmis impellucida & 5 & 30 & 0.40 & 28 & 5.76 & $2.64 \pm 0.15$ & 0.5 \\
\hline & & 4 & 20 & 0.43 & 24 & 4.40 & $0.63 \pm 0.15$ & 0.1 \\
\hline & Dunaliella tertiolecta & 5 & 30 & 0.01 & 15 & 0.08 & $0.68 \pm 0.05$ & 8.3 \\
\hline & & 5 & 20 & 0.02 & 13 & 0.10 & $0.42 \pm 0.02$ & 4.1 \\
\hline \multirow[t]{4}{*}{$26 \mathrm{May}$} & Tetraselmis impellucida & 4 & 30 & 0.63 & 25 & 0.60 & $3.50 \pm 0.81$ & 5.8 \\
\hline & & 3 & 20 & 0.35 & 0.6 & 0.10 & $2.38 \pm 1.12$ & 23.6 \\
\hline & Dunaliella tertiolecta & 5 & 30 & 0.04 & 12 & 0.20 & $1.09 \pm 0.27$ & 5.3 \\
\hline & & 5 & 20 & 0.04 & 7 & 0.13 & $0.10 \pm 0.03$ & 0.7 \\
\hline
\end{tabular}

C. hamatus. The smaller A. tonsa and P. crassirostris contained relatively less DMSP per individual. Labidocera sp., mainly a carnivorous species, contained less DMSP per individual than the smaller $T$. longicornis and $C$. hamatus. DMSP was detectable even after several hours of gut clearance. When expressed as carbon-specific DMSP content, $T$. longicornis and $C$. hamatus topped the list. Labidocera sp., owing to its high carbon content, contained less DMSP per unit carbon than the smaller A. tonsa.

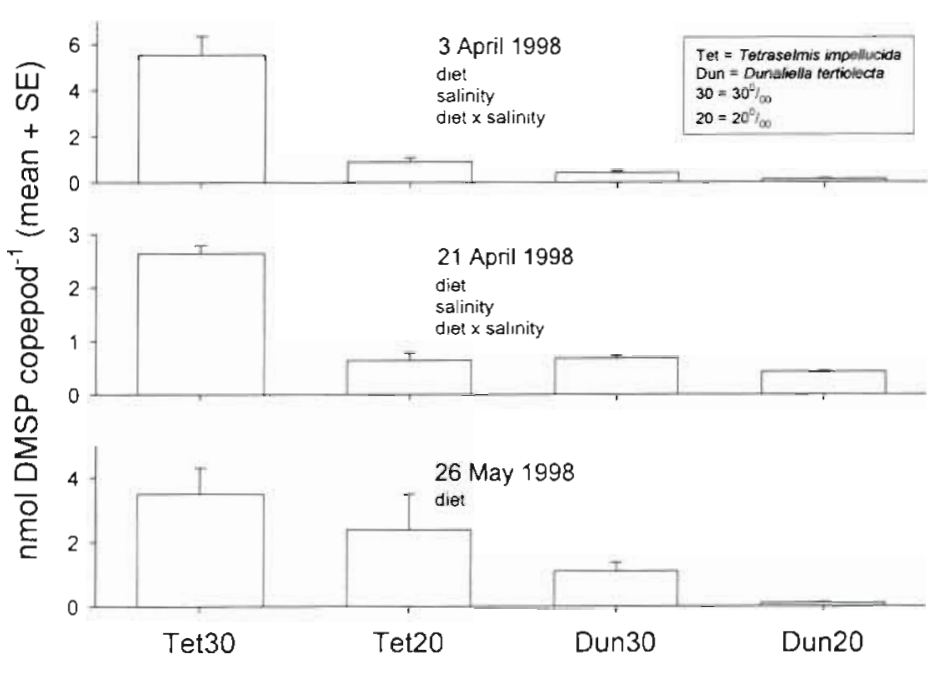

Fig. 1 Diet and salinity effect experiments with Temora longicornis. Food concentration was approximately $2 \times 10^{4}$ cells $\mathrm{ml}^{-1}$ in all treatments. DMSP content of the copepods was measured after $12 \mathrm{~h}$ gut clearance. Labels under date of experiments denote significant effects of diet, salinity or diet $\times$ salinity interaction $(2$-way ANOVA, $\mathrm{p}<0.05)$

\section{Efiects of food type and salinity}

We grew the phytoplankton in batch cultures and cell quality in terms of cellular DMSP content varied slightly between experiments. Nevertheless, Tetraselmis impellucida consistently contained an order of magnitude more cellular DMSP than Dunaliella tertiolecta (Table 2). Routine cell counts for the control bottles failed to indicate any substantial phytoplankton growth within $24 \mathrm{~h}$ (data not shown). We therefore calculated the ingestion rates assuming that the phytoplankton growth coefficient was zero (Eq. 7.9 in Omori \& Ikeda 1992) and that cellular DMSP concentration of the phytoplankton remained unchanged during the experiments (Table 2). Both food type and salinity had significant effects on the DMSP content of Temora longicornis and there was significant interaction between food type and salinity (2-way ANOVA, $p<0.05)$. One exception was the experiment on 26 May in which the salinity effect was not significant due to large variation in the $20 \%$ T. impellucida treatment. Nevertheless, within the same diet, higher salinity usually resulted in more DMSP per copepod (Fig. 1). $T$. longicornis contained 1.5 to 6 times more DMSP at the higher salinity when feeding on $T$. impellucida and 1.6 to 11 times when feeding on $D$. tertiolecta. Within the same salinity, there was a clear difference between the 2 food types. $T$. longicornis contained 3 to 13 times more DMSP when feeding on $T$. impellucida as compared with $D$. tertiolecta at $30 \%$, and 1.5 to 23 times more DMSP at $20 \%$ (Fig. 1). 


\section{Effects of salinity shift}

When fed Dunaliella tertiolecta, the DMSP content of Temora longicornis kept in the original salinity was not different from that of those transferred to higher or lower salinity ( $t$-test with unequal variances, $p>$ 0.05) (Fig. 2). On the Tetraselmis impellucida diet, the DMSP content of $T$. longicornis decreased significantly when transferred from 30 to $20 \%$ o ( $t$-test with unequal variances, $p<0.05$ ). Although a slight increase in DMSP content was observed when $T$. longicornis was transferred from 20 to $30 \%$, such an increase was statistically significant only on 1 of the 3 occasions (Fig. 2).

\section{Interacting effects of food concentration and salinity}

Food concentrations of Tetraselmis impellucida were equivalent to $0.61 \mu \mathrm{M}$ DMSP at $30 \%$ and $0.42 \mu \mathrm{M}$ DMSP at $20 \%$ for the high food concentration treatments and $0.06 \mu \mathrm{M}$ DMSP at $30 \%$ and $0.03 \mu \mathrm{M}$ DMSP at $20 \%$ for the low food concentration treatments (Table 3 ). Both food concentration and salinity had a significant effect on the DMSP content of Temora longicornis and the interaction between food concentration and salinity was also significant (2-way ANOVA, $p<0.05)$. At the same salinity, higher food concentration resulted in significantly more DMSP in T. longicornis (Fig. 3). Also, at similar food concentrations, higher salinity resulted in significantly more DMSP per copepod. The effect of salinity becomes more evident when one compares the treatments $30 \%$ low concentration (Lo) and $20 \%$ high concentration (Hi): despite a 20-fold lower food concentration at $30 \%$, T. longicornis contained about the same amount of DMSP as the ones at $20 \%$ with high food concentration. Gut clearance did not result in any significant loss of DMSP (2-tail t-test, p > 0.05) (Fig. 3).

Fig. 2. Salinity shift experiments with Temora Iongicornis. Food concentration was approximately $2 \times 10^{4}$ cells $\mathrm{ml}^{-1}$ in all treatments. DMSP conent of the copepods was measured after $12 \mathrm{~h}$ gut clearance. Number bars $(t$-test, $\mathrm{p}<0.05)$

\section{DISCUSSION}

\section{Copepods as a source of particulate DMSP}

Natural DMSP in the copepods may be a result of ingesting DMSP-containing food in the field. However, DMSP was detected even after several hours of gut clearance, suggesting that a portion of the DMSP is incorporated into the body tissue. We compared the carbon-specific DMSP content of the copepods (Table 1) with that of phytoplankton based on data from Keller \& Korjeff-Bellows (1996) (Table 4). We notice that phytoplankton DMSP contents may vary with culture conditions; nevertheless, such an exercise allows us to assess if the amount of DMSP found in the copepod biomass is within the range reported for phytoplankton in the literature. We estimated the phytoplankton cell volume using the linear dimensions

Table 3. Results for food concentration experiment with Tetraselmis impellucida as food. DMSP content of Temora longicornis after $12 \mathrm{~h}$ gut clearance are presented. $\mathrm{n}=$ sample size. See Table 2 for explanations on measurements of DMSP, calculation of ingestion rates and turnover time. Hi: high food concentration $\left(2 \times 10^{4} \mathrm{cells} \mathrm{m}^{-1}\right)$; Lo: low food concentration $\left(10^{3}\right.$ cells $\left.\mathrm{ml}^{-1}\right)$

\begin{tabular}{|c|c|c|c|c|c|c|}
\hline Treatment & $\mathrm{n}$ & $\begin{array}{l}\text { Salinity } \\
(\% 0)\end{array}$ & $\begin{array}{l}\text { Food concentration } \\
\text { (nmol DMSP } \mathrm{ml}^{-1} \text { ) }\end{array}$ & $\begin{array}{c}\text { Ingestion } \\
\left(\text { nmol ind. } .^{-1} \mathrm{~d}^{-1}\right)\end{array}$ & $\begin{array}{c}\text { DMSP content of } \\
\text { Temora longicornis } \\
\text { (mean } \pm \text { SE; nmol ind } .^{-1} \text { ) }\end{array}$ & $\begin{array}{c}\text { Turnover time } \\
\text { (d) }\end{array}$ \\
\hline $30 \% \mathrm{Hi}$ & 10 & 30 & 0.61 & 5.62 & $3.8 \pm 0.44$ & 0.7 \\
\hline $30 \%$ Lo & 13 & 30 & 0.06 & 0.09 & $1.51 \pm 0.13$ & 16.6 \\
\hline $20 \% \mathrm{Hi}$ & 11 & 20 & 0.42 & 7.85 & $1.28 \pm 0.05$ & 0.2 \\
\hline $20 \%$ Lo & 14 & 20 & 0.03 & 0.10 & $0.54 \pm 0.14$ & 5.6 \\
\hline
\end{tabular}




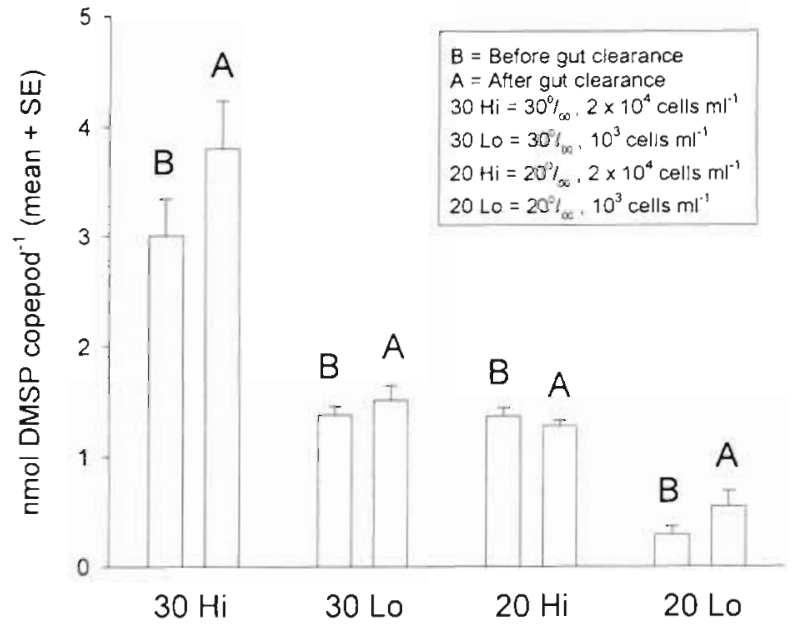

Fig. 3. Effects of different concentrations of Tetraselmis impellucida on the DMSP content of Temora longicornis at different salinities. Gut clearance did not result in less DMSP per copepod (2-tail $t$-test, $\mathrm{p}>0.05)$

given in the CCMP catalog (assuming cylindrical cells) and converted cell volume to cell carbon using Strathmann's equations (Strathmann 1967). We then used the data from Keller \& Korjeff-Bellows (1996) to calculate the carbon-specific DMSP content of the phytoplankton. The carbon-specific DMSP content of the copepod species in the present study 10.28 to $10.28 \mathrm{mg}$ DMSP $\mathrm{g}^{-1} \mathrm{C}$ ) is comparable to that of some diatoms, chlorophytes and cryptophytes (Table 4). Such comparison reveals that DMSP may be of similar physiological significance in the copepods as in these phytoplankton taxa. Since diatoms, chlorophytes and cryptophytes are known as minor DMSP producers (Keller \& Korjeff-Bellows 1996), it is likely that DMSP is a minor osmolyte in the copepods.

We used published data on the seasonal abundance of copepods in Long Island Sound to estimate the contribution by copepods to particulate DMSP concen- tration in the water column. Temora longicornis and Acartia hudsonica are the most common species in winter-spring whereas $A$. tonsa and Paracalanus sp. are mostly found in summer-fall in Long Island Sound (Peterson 1985, Smith 1995). We assumed that $A$. hudsonica has the same amount of DMSP per individual as $A$. tonsa. This is a reasonable assumption since both species are similar in size and salinity tolerance (Cervetto 1995). We calculated that copepod biomass accounts for 0.02 to $2.80 \mathrm{nM}$ DMSP in Long Island Sound and is a more important source of particulate DMSP in winterspring (Table 5). This is an underestimate of the total copepod DMSP pool because the abundances in Table 5 only represent the contribution by advanced copepodite and adult stages. Particulate DMSP concentration in Long Island Sound averages $3.61 \mathrm{nM}$ in spring (Tang et al. unpubl. data), which is at the lower end of reported particulate DMSP concentrations for estuaries (Iverson et al. 1989, Kiene \& Gerard 1995). Therefore, copepod biomass may account for up to $77 \%$ of particulate DMSP in the water column, depending on the season and species composition. Since commonly used water sampling methods usually fail to trap copepods and other actively swimming zooplankton, DMSP in copepods may represent a previously neglected source of particulate DMSP in the water column.

\section{Effects of food type and food concentration}

The difference in DMSP per individual of Temora longicornis between the 2 food types is consistent with the fact that Tetraselmis impellucida contained more DMSP than Dunaliella tertiolecta (Table 2). With the T. impellucida diet, higher food concentration aiso resulted in more DMSP per copepod (Fig. 3). When all data from Fig. 3 are combined, the bodily content of DMSP is curvilinearly related to DMSP ingestion (Fig. 4). Since the DMSP contents were measured

Table 4. Estimated carbon-specific DMSP content of phytoplankton based on data from Keller \& Korjeff-Bellows (1996). CCMP \# refers to strain numbers in catalog of the Provasoli-Guillard Center for Culture of Marine Phytoplankton. See text for details

\begin{tabular}{|c|c|c|c|}
\hline Taxonomic group & Species & CCMP \# & $\begin{array}{c}\text { Carbon-specific DMSP content } \\
\left(\mathrm{mg} \mathrm{DMSP} \mathrm{g}^{-1} \mathrm{C}\right)\end{array}$ \\
\hline Diatom & $\begin{array}{l}\text { Minidiscus trioculatus } \\
\text { Chaetoceros simplex } \\
\text { Cylindrotheca closterium } \\
\text { Thalassiosira pseudonana } \\
\text { Melosira nummuloides } \\
\text { Skeletonema costatum } \\
\text { Nitzchia laevis }\end{array}$ & $\begin{array}{r}495 \\
199 \\
342 \\
1335 \\
482 \\
1332 \\
560\end{array}$ & $\begin{array}{r}7.41 \\
3.53 \\
16.25 \\
7.00 \\
74.46 \\
36.79 \\
27.74\end{array}$ \\
\hline Chlorophyte & $\begin{array}{l}\text { Chlamydomonas sp. } \\
\text { Chlorella capsulata }\end{array}$ & $\begin{array}{l}231 \\
246\end{array}$ & $\begin{array}{l}0.18 \\
0.23\end{array}$ \\
\hline Cryptophyte & Rhodomonas salina & 1319 & 0.33 \\
\hline
\end{tabular}


Table 5. Contribution by copepods to particulate DMSP in Long Island Sound, USA. Abundance of copepods is for advanced copepodite stages and adult female only. 1: Smith (1995); 2: Dam \& Peterson (1993); 3: Beckman \& Peterson (1986)

\begin{tabular}{|c|c|c|c|c|c|}
\hline Species & Season & $\begin{array}{l}\text { Abundance } \\
\text { (ind. } \mathrm{m}^{-3} \text { ) }\end{array}$ & Data source & $\begin{array}{l}\text { DMSP content } \\
\left.\text { (nmol copepod }{ }^{-1}\right)\end{array}$ & $\begin{array}{c}\text { Total DMSP } \\
\text { (nM) }\end{array}$ \\
\hline Temora longicornis & Winter-spring & 2617 & 1,2 & 1.03 & 2.70 \\
\hline Acartia hudsonica & Winter-spring & 4821 & 1 & $0.02^{\mathrm{b}}$ & 0.10 \\
\hline Centropages sp. & Spring-summer & 53 & 1 & 0.81 & 0.04 \\
\hline Acartia tonsa & Summer-fall & 788 & 1,3 & 0.02 & 0.02 \\
\hline Paracalanus sp. & Summer-fall & 336 & 1 & 0.01 & 0.00 \\
\hline Labidocera sp. & Summer-fall & 7 & 1 & 0.08 & 0.00 \\
\hline
\end{tabular}

after gut clearance, this relationship demonstrates not an increase in gut content, but an increase in dietary DMSP incorporated into the copepod body tissue as ingestion rate increases. The DMSP content of T. longicornis approaches a constant beyond an ingestion rate of about 2 nmol DMSP copepod ${ }^{-1} \mathrm{~d}^{-1}$, indicating a saturation of bodily DMSP content. Consequently, one would expect that the copepods increasingly defecate, excrete or metabolize excess DMSP as ingestion rate continues to increase.

Wolfe et al. (1997) suggested that, when Emiliania huxleyi (Prymnesiophyceae) is grazed upon by protozoan, DMSP-lyase in the phytoplankton converts DMSP to DMS and acrylate. Because the protozoan preferentially fed on strains with lower lyase activity, Wolfe et al. (1977) suggested that DMSP in phytoplankton can serve as a defense mechanism against grazers, presumably due to the toxic effect of acrylate on the protozoan. In the present study, we observed an increase in ingestion rate of DMSP with increasing phytoplankton DMSP concentration. Therefore, DMSP in phytoplankton may not be, if at all, an effective defense mechanism against copepods.

Kwint \& Kramer (1996) proposed using DMSP derived from phytoplankton cells as a tracer for measuring zooplankton grazing activity. By following the decrease in DMSP gut content through time during defecation, as Kwint \& Kramer (1996) argued, one will obtain the gut clearance rate which allows ingestion rate to be computed. This method is desirable only if DMSP is neither broken down nor absorbed by the grazers. In our experiments, the final DMSP content of Temora longicornis could be as high as 5 times the DMSP content of field-collected individuals, indicating uptake of DMSP by the copepods during experiments. Also, contrary to Eurytemora affinis (Kwint \& Kramer 1996), T. longicornis contained large amounts of DMSP even after gut clearance. Therefore, it is unclear that DMSP can be used as a tracer for grazing experiments.

\section{Use of DMSP as an osmolyte in Temora longicornis}

The observations that Temora longicornis contained more DMSP at higher salinity regardless of food type (Fig. 1) suggest that the copepods engaged DMSP in osmoregulation. Further evidence is provided by the salinity shift experiments. When fed Tetraselmis impellucida, T. longicornis decreased or increased its bodily DMSP in response to a decrease or increase in ambient salinity (Fig. 1). Food type appears to affect how the copepods respond to salinity change, since $T$. longicornis feeding on Dunaliella tertiolecta showed little adjustment of DMSP content under changing salinity.

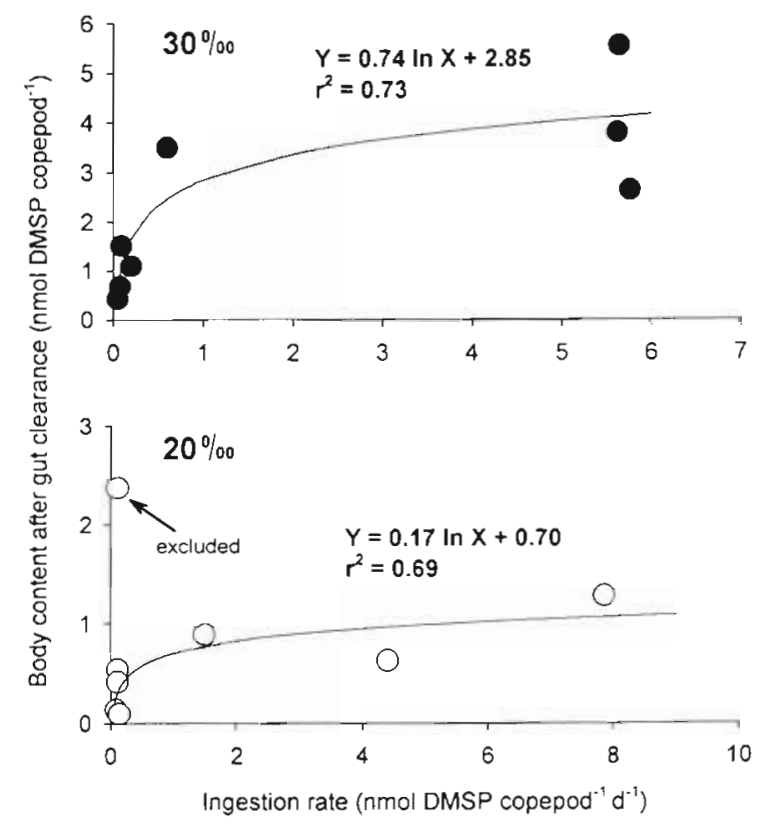

Fig. 4. DMSP content of Temora longicornis after gut clearance against ingestion rates at 30 and $20 \%$. Data are combined from all experiments in Fig. 3. Lines are fitted to the regressions 
It has been shown that estuarine copepods are able to osmoregulate by adjusting their bodily content of free amino acids (Farmer \& Reeve 1978, Burton \& Feldman 1982, Goolish \& Burton 1988, 1989). Both free amino acids and DMSP have the characteristics of compatible solutes and can serve as osmolytes in organisms. The amino acid methionine is the precursor of DMSP in both phytoplankton (Gage et al. 1997) and higher plants (Hanson \& Gage 1996), but such a pathway has not been found in animals. Acartia tonsa contains an internal pool of 400 to $3000 \mathrm{mmol} \mathrm{kg} \mathrm{kg}^{-1}$ dry wt of free amino acids for osmoregulation (Farmer \& Reeve 1978). Assuming that carbon constitutes $40 \%$ of the copepod's dry weight, we estimated that $A$. tonsa contains $1.7 \mathrm{mmol}$ DMSP kg-1 dry wt. The bigger Temora longicornis and Centropages hamatus contain about $30 \mathrm{mmol}$ DMSP kg-1 dry wt. Therefore, although DMSP appears to function as an osmolyte in copepods, it is far less significant than free amino acids.

\section{Implications for the dynamics of DMSP}

We reported the bodily DMSP content in 5 species of coastal marine copepods in their natural environment. These copepods represent a source of particulate DMSP in the water column. The amount of DMSP in copepods is regulated by supply (food type, food concentration) and demand (salinity). In a dynamic environment, such as coastal and estuarine waters, where food type, food concentration and salinity change temporally and spatially, the amount of DMSP in copepods will also change accordingly.

The stronger response to a decreasing salinity than to an increasing salinity indicates that the removal and accumulation of DMSP in Temora longicornis may be regulated by 2 different mechanisms. Since mortality was negligible in the experiments, different response of bodily DMSP content to increasing versus decreasing salinity obviously does not affect short-term survival of the copepods. Nevertheless, such a difference in response means that in an estuary, when a population of copepods moves up or down a salinity gradient, the resultant dynamics of DMSP is not simply a reversible process.

If one assumes that DMSP from ingested food is the only source of DMSP for the copepods, the minimum turnover time for DMSP in copepods can be calculated as DMSP content of the copepods after gut clearance divided by ingestion rate in terms of DMSP. In the present study, minimum turnover time ranges from several hours to a few days (Tables 2 \& 3). Except for 1 case, DMSP turnover time is longer at higher salinity within the same diet. Turnover time is also much longer at low food concentration within the same salinity. Therefore, one will expect that in a highly saline and nutritionally dilute environment, such as the open ocean, copepod biomass represents a relatively stationary reservoir of particulate DMSP in the water column and thus becomes an important source of DMSP for higher trophic organisms. In contrast, in a productive and less saline environment, such as coastal and estuarine waters, copepod biomass will represent a dynamic pool of particulate DMSP. Consequently, the feeding ecology of the copepods and the fate of DMSP in the copepod body tissue become important to the dynamics of DMSP in the water column.

In conclusion, future modeling work on DMSP dynamics needs to consider copepod biomass as a source of DMSP, its relation to phytoplankton and its response to ambient salinity. Although we have shown that the copepods can adjust bodily DMSP content in response to changing salinity, the mechanisms behind such adjustment are still unknown. Future effort should focus on the biochemical pathways of DMSP in copepods, which is crucial to a better understanding of the impact marine copepods may have on the global DMSP dynamics.

Acknowledgements. This study was supported by grants NSF OCE-9521907 (CAREER) awarded to H.G.D. and Sigma Xi GIAR awarded to K.W.T. The Marine Science and Technology Center of the University of Connecticut (MSTC, UCONN) provided research vessels. Three anonymous reviewers provided helpful comments. This is contribution no. 306 of the MSTC, UCONN.

\section{LITERATURE CITED}

Andreae MO (1990) Ocean-atmosphere interactions in the global biogeochemical sulfur cycle. Mar Chem 30:1-29

Andreae MO, Raemdonck $H$ (1983) Dimethyl sulfide in the surface ocean and the marine atmosphere: a global view. Science 221:744-747

Beckman BR, Peterson WT (1986) Egg production by Acartia tonsa in Long Island Sound. J Plankton Res 8:917-925

Belviso S, Kim SK, Rassoulzadegan F, Krajka B, Nguyen BC, Mihalopoulos N, Menard-Buat P (1990) Production of dimethyl sulfonium propionate (DMSP) and dimethylsulfide (DMS) by a microbial food web. Limnol Oceanogr 35:1810-1821

Burton RS, Feldman MW (1982) Changes in free amino acid concentrations during osmotic response in the intertidal copepod Tigriopus californicus. Comp Biochem Physiol $73: 441-445$

Cervetto $G$ (1995) Comparaison de la répartition spatio-temporelle et de l'écophysiologie de deux espèces de copépodes calanoïdes congénériques (Acartia tonsa et Acartia clausi) en milieu côtier et lagunaire (Golfe de Fos, Etang de Berre). PhD thesis. Universite D'Aix-Marseille II

Charlson RJ, Lovelock JE, Andreae MO, Warren SG (1987) Oceanic phytoplankton, atmospheric sulphur, cloud albedo and climate. Nature 326:655-661

Dacey JWH, Blough NV (1987) Hydroxide decomposition of dimethyl sulfoniopropionate to form dimethylsulfide. Geophys Res Lett 14:1246-1249

Dacey JWH, Wakeham SG (1986) Oceanic dimethylsulfide: production during zooplankton grazing on phytoplankton. Science 238:1314-1316 
Dacey JWH, King GM, Lobel PS (1994) Herbivory by reef fishes and the production of dimethylsulfide and acrylic acid. Mar Ecol Prog Ser 112:67-74

Daly KL, DiTullio GR (1996) Particulate dimethylsulfoniopropionate removal and dimethylsulfide production by zooplankton in the southern ocean. In: Kiene RP, Visscher PT, Keller MD, Kirst GO (eds) Biological and environmental chemistry of DMSP and related sulfonium compounds Plenum Press, New York, p 223-238

Dam HG, Peterson WT (1988) The effect of temperature on the gut clearance rate constant of planktonic copepods J Exp Mar Biol Ecol 123:1-14

Dam HG, Peterson WT (1993) Seasonal contrasts in the diel vertical distribution, feeding behavior, and grazing impact of the copepod Temora longicornis in Long Island Sound. J Mar Res 51:561-594

Farmer L (1980) Evidence for hyporegulation in the calanoid copepod, Acartia tonsa. Comp Biochem Physiol 65:359-362

Farmer L, Reeve MR (1978) Role of the free amino acid pool of the copepod Acartia tonsa in adjustment to salinity change. Mar Biol 48:311-316

Gabric A, Murray N, Stone L, Kohl M (1993) Modelling the production of dimethylsulfide during a phytoplankton bloom. J Geophys Res 98:22805-22816

Gage DA, Rhodes D, Nolte KD, Hicks WA, Leustek T, Cooper AJL, Hanson AD (1997) A new route for synthesis of dimethylsulphoniopropionate in marine algae. Nature 387:891-894

Goolish EM, Burton RS (1988) Exposure to fluctuating salinity enhances free amino acid accumulation in Tigriopus californicus (Copepoda). J Comp Physiol 158:99-105

Goolish EM, Burton RS (1989) Energetics of osmoregulation in an intertidal copepod: effects of anoxia and lipid reserves in the pattern of free amino acid accumulation. Funct Ecol 3:81-89

Guillard RRL (1975) Culture of phytoplankton for feeding marine invertebrates. In: Smith WL, Chanley MH (eds) Culture of marine invertebrate animals. Plenum Press, New York, p 26-60

Hanson AD, Gage DA (1996) 3-dimethylsulfoniopropionate biosynthesis and use by flowering plants. In: Kiene RP, Visscher PT, Keller MD, Kirst GO (eds) Biological and environmental chemistry of DMSP and related sulfonium compounds. Plenum Press, New York, p 75-86

Hill RW, Dacey JWH, Krupp DA (1995) Dimethylsulfoniopropionate in reef corals. Bull Mar Sci 57:489-494

Iverson RL, Nearhoof FL, Andreae MO (1989) Production of dimethylsulfonium propionate and dimethylsulfide by phytoplankton in estuarine and coastal waters. Limnol Oceanogr 34:53-67

Keller MD, Korjeff-Bellows W (1996) Physiological aspects of the production of dimethylsulfoniopropionate (DMSP) by marine phytoplankton. In: Kiene RP, Visscher PT, Keller MD, Kirst GO (eds) Biological and environmental chemistry of DMSP and related sulfonium compounds. Plenum Press, New York, p 131-142

Kiene RP, Bates TS (1990) Biological removal of dimethyl sulphide from sea water. Nature 345:702-705

Kiene RP, Gerard G (1995) Evaluation of glycine betaine as an inhibitor of dissolved dimethylsulfoniopropionate degradation in coastal waters. Mar Ecol Prog Ser 128:121-131

Kiene RP, Service SK (1991) Decomposition of dissolved DMSP and DMS in estuarine waters: dependence on temperature and substrate concentration. Mar Ecol Prog Ser $76: 1-11$

Kirst GO (1996) Osmotic adjustment in phytoplankton and macroalgae. In: Kiene RP, Visscher PT, Keller MD, Kirst
GO (eds) Biological and environmental chemistry of DMSP and related sulfonium compounds. Plenum Press, New York, p 121-129

Kwint RLJ, Kramer KJM (1996) A new sensitive tracer for the determination of zooplankton grazing activity. J Plankton Res 18:1513-1518

Kwint RLJ, Irigoien X, Kramer KJM (1996) Copepods and DMSP. In: Kiene RP, Visscher PT, Keller MD, Kirst GO (eds) Biological and environmental chemistry of DMSP and related sulfonium compounds. Plenum Press, New York, p 239-252

Ledyard KM, Dacey JWH (1994) Dimethylsulfide production from dimethylsulfoniopropionate by a marine bacterium. Mar Ecol Prog Ser 110:95-103

Lovelock JE, Maggs RJ, Rasmussen RA (1972) Atmospheric dimethyl sulfide and the natural sulfur cycle. Nature 237 $452-453$

Malin G (1996) The role of DMSP and DMS in the global sulfur cycle and climate regulation. In: Kiene RP, Visscher PT, Keller MD, Kirst GO (eds) Biological and environmental chemistry of DMSP and related sulfonium compounds. Plenum Press, New York, p 171-189

Matrai PA, Keller MD (1994) Total organic sulfur and dimethylsulfoniopropionate in marine phytoplankton: intracellular variations. Mar Biol 119:61-68

Nakajima K (1996) Effects of DMSP and related compounds on behavior, growth and stress resistance of fish, amphibians and crustaceans. In: Kiene RP, Visscher PT, Keller MD, Kirst GO (eds) Biological and environmental chemistry of DMSP and related sulfonium compounds. Plenum Press, New York, p 165-176

Nguyen BC, Gaudry A, Bonsang B, Lamber G (1978) Reevaluation of the role of dimethyl sulphide in the sulphur budget. Nature 275:637-639

Nguyen BC, Bonsang B, Gaudry A (1983) The role of the ocean in the global atmospheric sulfur cycle. J Geophys Res 88:10903-10914

Omori M, Ikeda T (1992) Methods in marine zooplankton ecology. Krieger, Malabar, FL

Peterson WT (1985) Abundance, age structure and in situ egg production rates of the copepod Temora longicornis in Long Island Sound, New York. Bull Mar Sci 37:726-738

Smith GE (1995) Copepods and euthrophication in Long Island Sound. MSc thesis, Univ of Connecticut

Stefels J, van Boekel WHM (1993) Production of DMS from dissolved DMSP in axenic cultures of the marine phytoplankton species Phaeocystis sp. Mar Ecol Prog Ser 97 . $11-18$

Strathmann RR (1967) Estimating the organic carbon content of phytoplankton from cell volume or plasma volume. Limnol Oceanogr 12:411-418

Visscher PT (1996) Microbial turn-over of volatile sulfur compounds. In: Mursell JC, Kelly DP (eds) Microbiology of atmospheric trace gases. Springer, New York, p 227-242

Wolfe GV (1992) The cycling of climatically active dimethyl sulfide (DMS) in the marine euphotic zone: biological and chemical constraints on the flux to the atmosphere. PhD thesis, University of Washington

Wolfe GV, Steinke M (1996) Grazing-activated production of dimethyl sulfide (DMS) by two clones of Emiliania huxleyi. Limnol Oceanogr 41:1151-1160

Wolfe GV, Sherr EB, Sherr BF (1994) Release and consumption of DMSP from Emiliania huxleyi during grazing by Oxyrrhis marina. Mar Ecol Prog Ser 111:111-119

Wolfe GV, Steinke M, Kirst GO (1997) Grazing-activated chemical defence in a unicellular marine alga. Nature 387 : 894-897 